\title{
PROFESSIONAL IDENTITY OF HIGHER EDUCATION TEACHERS IN SAMPLES OF RIGA AND SMOLENSK
}

\author{
Jelena Jermolajeva \\ University College of Economics and Culture, Latvia \\ Tatiana Bogdanova \\ Smolensk State University, Russia
}

\begin{abstract}
In most studies on professional identity (PI) of teachers, the subject of research is the PI of a school teacher; far less attention is paid to teachers working at higher education institutions (HEI). The aim of this article is to study the model of HEI teachers' professional identity by a general comparative analysis of the indicators of its structural components in samples of Riga and Smolensk. The structural components of the proposed model are philosophy of the profession, professional knowledge, professional roles, professional attitude to work, cooperation with colleagues, professional engagement behaviors. To test the relevance of the model, a questionnaire was created with 60 items, and a survey of university teachers was carried out. In total, 198 teachers were surveyed in Riga and Smolensk. The obtained results show the relevance of the proposed model of teachers' PI and the technique developed to study it. All the components of the model have high average scores and correlate well with each other. The lack of statistically significant differences in both survey samples points out that the PIs of teachers have much in common, regardless of the country of residence and features of the national educational systems. The elaborated technique can be applied as the tool of evaluation/self-evaluation of HEI teachers' PI to improve the educational process.
\end{abstract}

Keywords: professional identity (PI), teacher of higher education institution, the model of the of PI, structural components of the model of PI.

\section{Introduction}

Teacher is a key figure in the implementation of educational reforms. Pedagogical research of the personality of teacher, her/his priority values, selfevaluation, and the way how she/he conceptualizes the profession at an individual level can lead to the most appropriate strategies to manage the educational reforms successfully (Radulescu, 2013). There is “... a simple reason to look at the Self of the teacher..., for as long as we don't know ourselves deeply, we are disconnected from our students, colleagues, the profession and the subject matter we teach" (Bukor, 2011: 126). 
The study of the professional identity (PI) of a teacher began relatively recently, in the nineties of the $20^{\text {th }}$ century. In most studies on this theme, the subject of research is the PI of a school teacher; far less attention was paid to college and university teachers.

The PI of a teacher of higher education institution (HEI) has become one of the main themes of the international research project "Professional identity of educators", carried out by a group of scientists of the Riga Teacher Training and Education Management Academy (Latvia) and Smolensk State University (Russia) including the authors of this paper $(2014-2016$, coordinated by A. Špona and N. P. Senchenkov). In the realization of the project a rich empirical material was obtained and a number of analytical articles were published (Шпона et al., 2015; Špona, 2016; Bogdanova, 2016; Silchenkova, 2016; Сильченкова \& Ермолаева, 2016).

The aim of this article is to study the model of HEI teachers' professional identity by a general comparative analysis of the indicators of its structural components in samples of Riga and Smolensk. The model of contents of HEI teachers' PI was created in the course of the implementation of the abovementioned project on the basis of analysis and generalization of scientific literature (Emerson, 2010; Beijaard et al., 2004; Healey \& Hays, 2011; Woo, 2013). Six main interacting structural components of the PI were identified (see Fig. 1):

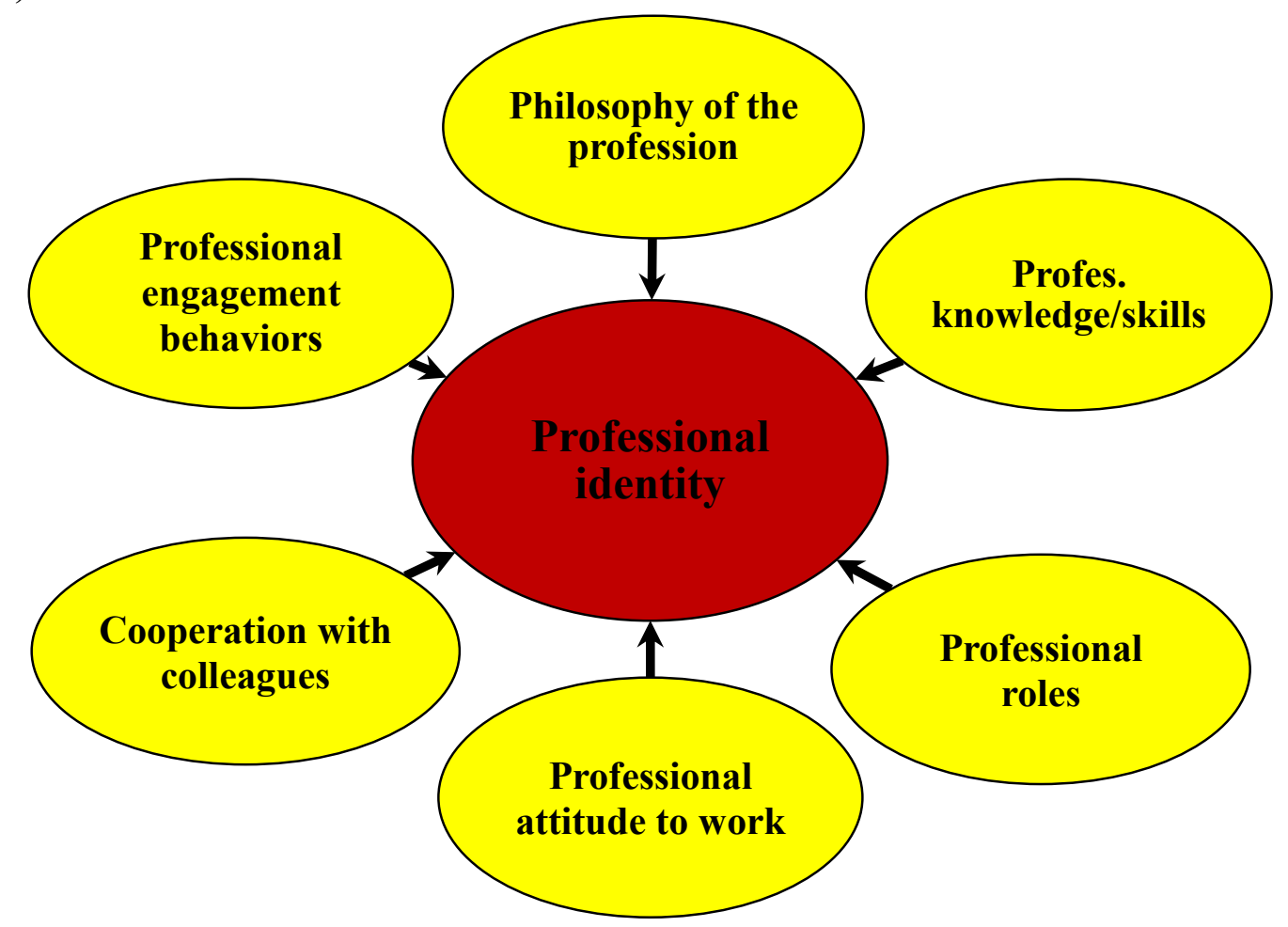

Figure 1 The structural components of the HEI teachers' PI (Шпона et al., 2015) 
1. Philosophy of the profession - basic professional values and patterns: the belief in the necessity and importance of the work, the goals of professional work, professional ethics.

2. Professional knowledge (on the subject taught, in pedagogy, psychology, research, knowledge of foreign languages at the professional level) and skills (the ability to apply this knowledge).

3. Implementation of professional roles (teacher, curator, researcher, head of the structural unit, etc.).

4. Professional attitude to work: engagement and motivation in work, professional honesty and conscientiousness, high demands on themselves, respect for students.

5. Cooperation with colleagues in daily work, professional organizations, research projects, publications, etc.

6. Professional engagement behaviors - the behavior that is not connected with the implementation of direct professional duties, but corresponds to the philosophy of the profession (adoption of the mission of education, participation in the formulation and solution of social problems containing pedagogical aspects, unselfish professional help to those who need it, etc.) (Шпона et al., 2015).

Methods and research base. The methodological base of research has been developed using the Professional Identity Scale in Counseling by H. Woo, which was proposed for the profession of psychologist-counselor (Woo, 2013). This technique has been modified to investigate the contents of higher education teachers' professional identity. As a result, a questionnaire was created with 60 items, and a survey of university teachers was carried out. In total, 198 teachers were surveyed in Riga and Smolensk.

Testing was anonymous. 118 teachers of Riga Teacher Training and Education Management Academy, Latvian Academy of Sport Education, Latvian Academy of Music, Riga Technical University were surveyed in Latvia. In Russia, 80 representatives of the four leading higher education institutions of Smolensk were surveyed: Smolensk State University, Smolensk State Medical University, Smolensk State Agricultural Academy, Smolensk Academy of Physical Culture, Sports and Tourism.

The questionnaire contained 6 blocks, corresponding to 6 main components of the model of the higher education teacher identity. Every block consisted of 10 statements, which can be evaluated by the appropriate rating: from the strong disagreement (1 point) to the complete agreement ( 6 points).

The reliability of the questionnaire was tested by the method of Cronbach's alpha; the obtained indicator 0.84 suffices to recognize it as reliable.

Using the coefficient of Mann-Whitney, statistically significant differences were identified. Within each block of statements and between the blocks, 
Jelena Jermolajeva, Tatiana Bogdanova. Professional Identity of Higher Education Teachers in Samples of Riga and Smolensk

Spearman's rank correlations coefficient were defined by means of Statistica software. The cases of significant correlation have been analyzed.

\section{Results}

The distribution of participants from Riga and Smolensk samples by gender, age, work experience and presence/absence of a scientific degree are presented in Table 1. In both countries, these data reflect approximately the corresponding distribution of teaching staff in the participating HEI taken together.

Table 1 Characteristics of Riga and Smolensk samples

\begin{tabular}{|l|c|c|c|c|c|c|c|c|c|c|}
\hline & & \multicolumn{4}{|c|}{ Age } & \multicolumn{4}{|c|}{ Work experience } & Sc. degree \\
\cline { 3 - 11 } & F/M (\%) & Mean & $\begin{array}{c}\text { Up to } \\
35 \\
(\%)\end{array}$ & $\begin{array}{c}36- \\
55 \\
(\%)\end{array}$ & $\begin{array}{c}56 \text { and } \\
\text { above } \\
(\%)\end{array}$ & $\begin{array}{c}\text { Mean } \\
\text { (\%p to } \\
5\end{array}$ & $\begin{array}{c}6-15 \\
(\%)\end{array}$ & $\begin{array}{c}16 \text { and } \\
\text { above } \\
(\%)\end{array}$ & $\begin{array}{c}\text { Dr. or } \\
\text { candidate } \\
/ \text { Mg. }(\%)\end{array}$ \\
\hline Riga & $76,3 / 23,7$ & 52,8 & 8,5 & 49,2 & 42,4 & 20,0 & 7,6 & 28,0 & 64,4 & $57,6 / 42,4$ \\
\hline Smo & $76,4 / 23,6$ & 42,3 & 26,3 & 57,5 & 16,3 & 14,8 & 20,0 & 47,5 & 32,5 & $80 / 20$ \\
\hline
\end{tabular}

The ratio of women/men is about the same: 76,3/23,7 in Riga and 76,4/23,6 in Smolensk. This ratio indicates that in both countries the profession of university teacher, as well as school teacher, is a predominantly female. However, in these two samples significant differences were detected in distribution by age, work experience and the presence/absence of a scientific degree (Fig. 2). The average age of Smolensk teachers is 11 years less than that of Riga teachers; at the same time their average work experience is only 5 years less than that of teachers in Riga. 64,4\% of Latvian teachers have work experience more than 15 years (in Smolensk this indicator is $32,5 \%$ ). In addition, proportion of teachers with a degree in Smolensk $(80,00 \%)$ is essentially higher than in Riga $(56,7 \%)$. These data suggest the continuity of generations in Smolensk universities teaching staff; they also indicate that younger Smolensk HEI teachers are more active in research activities, successfully defend dissertations and obtain scientific degrees. These differences demonstrate the alarming situation in Riga in the HEI teaching staff structure.

In all the components of PI mean rates, dispersion, standard deviation, statistical mode, and coefficient of variation $(\mathrm{CoV})$ were calculated for both samples of respondents ( $\mathrm{CoV}$ up to $33 \%$ is considered to be reliable and accurate to draw conclusions). The data are shown in Table 2. The numbers are separated by a slash: the first, in bold is an indicator for Riga; the second in italics refers to the Smolensk teachers. 

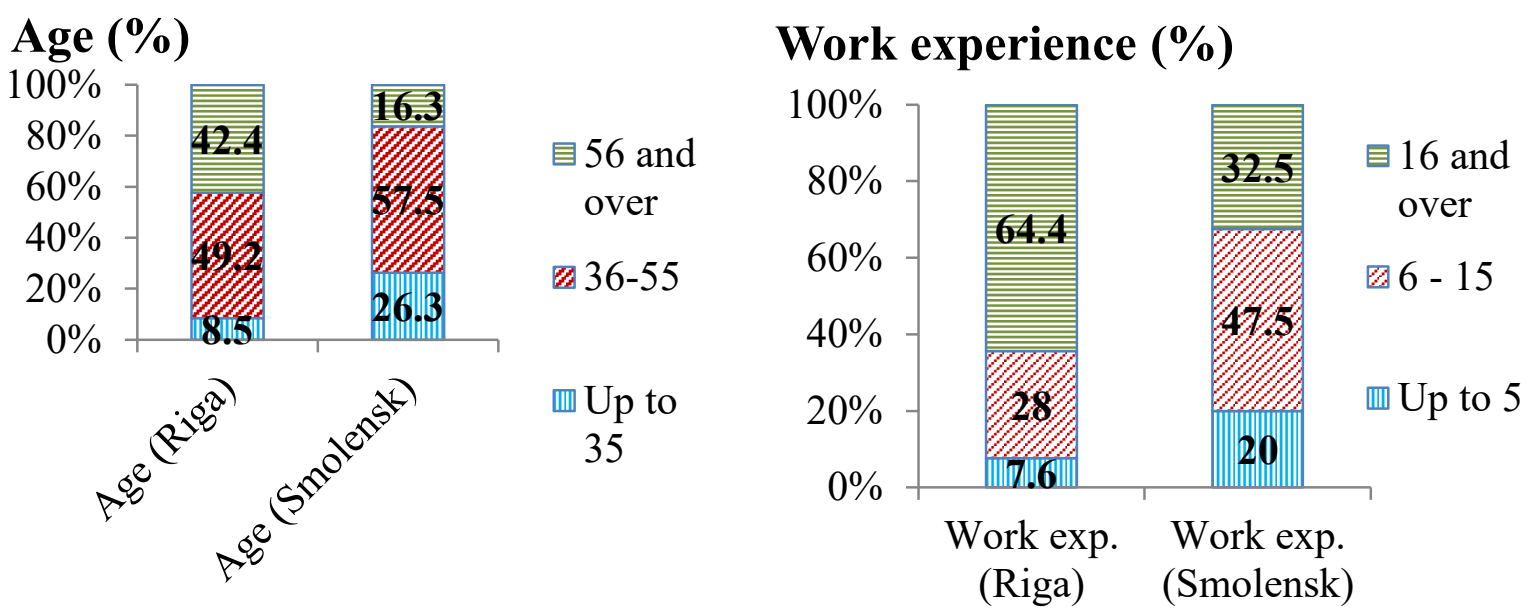

Figure 2 Distribution of participants from Riga and Smolensk samples by age and work experience

Table 2 Statistical indicators of the structural components of PI of HEI teachers (Riga /Smolensk)

\begin{tabular}{|l|c|c|c|c|c|}
\hline $\begin{array}{c}\text { Structural } \\
\text { components }\end{array}$ & $\begin{array}{c}\text { Mean } \\
\text { values }\end{array}$ & Dispersion & $\begin{array}{c}\text { Standard } \\
\text { deviation }\end{array}$ & $\begin{array}{c}\text { Coefficients of } \\
\text { variation (\%) }\end{array}$ & Mode \\
\hline $\begin{array}{l}\text { 1. Philosophy of the } \\
\text { profession }\end{array}$ & $\mathbf{5 , 1 9} / 5,12$ & $\mathbf{0 , 9 7} / 0,99$ & $\mathbf{0 , 9 9} / 1,00$ & $\mathbf{1 9 , 0 2} / 19,46$ & $\mathbf{6} / 6$ \\
\hline $\begin{array}{l}\text { 2. Professional } \\
\text { knowledge }\end{array}$ & $\mathbf{4 , 8 2} / 4,71$ & $\mathbf{1 , 1 5} / 1,49$ & $\mathbf{1 , 0 7 / 1 , 2 2}$ & $\mathbf{2 2 , 2 0 / 2 5 , 9 1}$ & $\mathbf{5} / 5$ \\
\hline 3. Professional roles & $\mathbf{4 , 9 3} / 4,87$ & $\mathbf{1 , 3 4} / 1,30$ & $\mathbf{1 , 1 6} / 1,14$ & $\mathbf{2 3 , 4 6 / 2 3 , 4 5}$ & $\mathbf{6} / 5$ \\
\hline $\begin{array}{l}\text { 4. Professional } \\
\text { attitude to work }\end{array}$ & $\mathbf{4 , 8 8} / 4,94$ & $\mathbf{1 , 2 7} / 1,03$ & $\mathbf{1 , 1 3} / 1,05$ & $\mathbf{2 3 , 0 8 / 2 1 , 1 9}$ & $\mathbf{5} / 5$ \\
\hline $\begin{array}{l}\text { 5. Cooperation with } \\
\text { colleagues }\end{array}$ & $\mathbf{4 , 4 9} / 4,07$ & $\mathbf{1 , 9 2} / 2,51$ & $\mathbf{1 , 3 9} / 1,58$ & $\mathbf{3 0 , 9 3 / 3 8 , 9 2}$ & $\mathbf{5} / 5$ \\
\hline $\begin{array}{l}\text { 6. Professional } \\
\text { Engagement } \\
\text { Behaviors }\end{array}$ & $\mathbf{4 , 3 6} / 4,00$ & $\mathbf{2 , 3 5} / 2,52$ & $\mathbf{1 , 5 3} / 1,59$ & $\mathbf{3 5 , 1 7} / 39,65$ & $\mathbf{6} / 5$ \\
\hline
\end{tabular}

The similarity of the results for both samples indicates to the relevance of the proposed model of contents of HEI teachers' PI. High rates of all the 6 components also confirm this (all modes are 5 or 6 , which corresponds to "completely agree").

The results show that on the whole the answers of the Russians and Latvians in the questionnaire are fairly well agreed, despite the fact that during last 25 years the two public educational systems developed independently. According to the Mann-Whitney coefficient, the differences between the two samples of respondents are not statistically significant either for the PI taken as coherent whole, or for each component separately. Even for the components "Cooperation 
Jelena Jermolajeva, Tatiana Bogdanova. Professional Identity of Higher Education Teachers in Samples of Riga and Smolensk

with colleagues" and "Professional engagement behaviors", where the coefficients of variation in both cities are too high to be reliable, no statistically significant differences between the samples were observed (Table 3).

Table 3 Statistical differences between the variables in Riga and Smolensk samples

\begin{tabular}{l}
\multicolumn{8}{|c|}{ Mann-Whitney U-test for variable PI (Smolensk). The criteria shown are significant for p } \\
\hline \\
\hline
\end{tabular}

High coefficients of variation for these two components indicate that the attitude and behavior of teachers in these professional areas are far more personalized compared to other components. It is noteworthy that this fact does not depend on nationality and the characteristics of national educational space. Cooperation with colleagues is recognized by almost everyone as necessary and useful for the professional ("To improve my qualification I attend professional training sessions and participate in professional associations", "Participation in research projects helps me to extend my professional competence", "Every year I participate actively in conferences and seminars"). Nevertheless, a particularly individual style of communication and the situation in the working collective have great influence on this cooperation (the coefficients of variation of answers in the items "In discussions with colleagues, the most important for me is to defend my point of view", "For my professional development I regularly consult with colleagues and try to find out their opinions on my work" are more than $33 \%$ in both samples). At the same time the data also indicate to certain differences between some trends in the analyzed professional communities of the two countries. Latvians are more experienced in international cooperation than their 
Russian colleagues: in Riga, the item "I have experience of academic and research work at foreign universities" has mode 5 and coefficient of variation $30,77 \%$, while Smolensk answers have mode 1 ("strongly disagree") and exclusively high coefficient of variation $81,97 \%$. "The experience of communication with foreign colleagues in foreign languages" obtained mode 5 and $\mathrm{CoV} 30.77 \%$ in Riga, mode 1 and CoV $61.43 \%$ in Smolensk. On the other hand, the participants of the Smolensk sample on the whole more actively publish scientific and methodical papers (CV $24.43 \%$ ), while the publishing activity of the teachers from Riga is to a greater extent an individual parameter (CoV 36.08).

High general variability of responses in the component "Professional engagement behaviors" (in Riga CoV is $35.17 \%$, in Smolensk $39.65 \%$ ) points out that in both countries there are socially active teachers, and there are more passive. On the whole, however, teachers are characterized by the belief that "the teaching profession is unique and valuable for the development of society" (mode 6 and $\mathrm{CoV} 26.94 \%$ in the total sample). The high degree of consensus and low variability are also fixed in the statements about mission of education, which is necessary to carry out for professional (mode $5-6$ ): "I believe that the teacher's duty - to enhance the culture of behavior in the social environment", "If necessary, I will gladly consult pupils, students and other people who may need my professional help".

Using correlation analysis, the interdependencies between the structural components and their influences on the general PI were determined. Spearman's rank correlations for each component are shown in the Table 4. The components' correlations with the general PI are underlined.

Table 4 Spearman's rank correlations of components with general PI and with other components (Riga / Smolensk)

\begin{tabular}{|c|c|c|c|c|c|c|c|}
\hline & PI & $\begin{array}{l}\text { Comp. } \\
\text { No. } 1\end{array}$ & $\begin{array}{l}\text { Comp. } \\
\text { No. } 2\end{array}$ & $\begin{array}{l}\text { Comp. } \\
\text { No. } 3\end{array}$ & $\begin{array}{l}\text { Comp. } \\
\text { No. } 4\end{array}$ & $\begin{array}{l}\text { Comp. } \\
\text { No. } 5\end{array}$ & $\begin{array}{l}\text { Comp. } \\
\text { No.6 }\end{array}$ \\
\hline PI & 1,00 & $\begin{array}{c}\mathbf{0 , 6 9} / \\
0,49\end{array}$ & $\begin{array}{c}\mathbf{0 , 6 9 /} \\
0,62\end{array}$ & $\begin{array}{c}\mathbf{0 , 8 0} / \\
0,75\end{array}$ & $\begin{array}{c}\mathbf{0 , 7 5} / \\
0,78\end{array}$ & $\begin{array}{c}\mathbf{0 , 8 4} / \\
0,76\end{array}$ & $\begin{array}{c}\mathbf{0 , 8 8} / \\
0,72\end{array}$ \\
\hline $\begin{array}{l}\text { Comp. } \\
\text { No. } 1\end{array}$ & $\begin{array}{c}\mathbf{0 , 6 9} / \\
0,49\end{array}$ & 1,00 & $\begin{array}{c}\mathbf{1 , 0 0 /} \\
0,15\end{array}$ & $\begin{array}{c}\mathbf{0 , 6 2} / \\
0,34\end{array}$ & $\begin{array}{c}\mathbf{0 , 5 8} / \\
0,45\end{array}$ & $\begin{array}{c}\mathbf{0 , 4 3} / \\
0,33\end{array}$ & $\begin{array}{c}\mathbf{0 , 5 5} / \\
0,23\end{array}$ \\
\hline $\begin{array}{l}\text { Comp. } \\
\text { No. } 2\end{array}$ & $\begin{array}{c}\mathbf{0 , 6 9 /} \\
0,62\end{array}$ & $\begin{array}{c}\mathbf{1 , 0 0 /} \\
0,15\end{array}$ & 1,00 & $\begin{array}{c}\mathbf{0 , 6 2} / \\
0,57\end{array}$ & $\begin{array}{c}\mathbf{0 , 5 8} / \\
0,40 \\
\end{array}$ & $\begin{array}{c}\mathbf{0 , 4 3} / \\
0,50 \\
\end{array}$ & $\begin{array}{c}\mathbf{0 , 5 5} / \\
0,28 \\
\end{array}$ \\
\hline $\begin{array}{l}\text { Comp. } \\
\text { No. } 3\end{array}$ & $\begin{array}{c}\mathbf{0 , 8 0} / \\
0,75\end{array}$ & $\begin{array}{c}\mathbf{0 , 6 2} / \\
0,34\end{array}$ & $\begin{array}{c}\mathbf{0 , 6 2} / \\
0,57\end{array}$ & 1,00 & $\begin{array}{c}\mathbf{0 , 7 0} / \\
0,54\end{array}$ & $\begin{array}{c}\mathbf{0 , 5 7} / \\
0,48\end{array}$ & $\begin{array}{c}\mathbf{0 , 5 9} / \\
0,45\end{array}$ \\
\hline $\begin{array}{l}\text { Comp. } \\
\text { No. } 4\end{array}$ & $\begin{array}{c}\mathbf{0 , 7 5} / \\
0,78\end{array}$ & $\begin{array}{c}\mathbf{0 , 5 8} / \\
0,45\end{array}$ & $\begin{array}{c}\mathbf{0 , 5 8} / \\
0,40\end{array}$ & $\begin{array}{c}\mathbf{0 , 7 0} / \\
0,54\end{array}$ & 1,00 & $\begin{array}{c}\mathbf{0 , 5 2} / \\
0,50\end{array}$ & $\begin{array}{c}\mathbf{0 , 6 8 /} \\
0,47\end{array}$ \\
\hline $\begin{array}{l}\text { Comp. } \\
\text { No. } 5\end{array}$ & $\begin{array}{c}\mathbf{0 , 8 4} / \\
0,76\end{array}$ & $\begin{array}{c}\mathbf{0 , 4 3} / \\
0,33\end{array}$ & $\begin{array}{c}\mathbf{0 , 4 3} / \\
0,50\end{array}$ & $\begin{array}{c}\mathbf{0 , 5 7} / \\
0,48\end{array}$ & $\begin{array}{c}\mathbf{0 , 5 2} / \\
0,50\end{array}$ & 1,00 & $\begin{array}{c}\mathbf{0 , 7 1} / \\
0,43\end{array}$ \\
\hline $\begin{array}{l}\text { Comp. } \\
\text { No. } 6\end{array}$ & $\begin{array}{c}\mathbf{0 , 8 8} / \\
0,72\end{array}$ & $\begin{array}{c}\mathbf{0 , 5 5} / \\
0,23\end{array}$ & $\begin{array}{c}\mathbf{0 , 5 5} / \\
0,28\end{array}$ & $\begin{array}{c}\mathbf{0 , 5 9} / \\
0,47\end{array}$ & $\begin{array}{c}\mathbf{0 , 6 8} / \\
0,47\end{array}$ & $\begin{array}{c}\mathbf{0 , 7 1 /} \\
0,43\end{array}$ & 1,00 \\
\hline
\end{tabular}


Statistically significant correlations are over 0,3 . All the 6 components have moderately strong (over 0,5 and up to 0,7 ) and strong (over 0,7 ) correlations with the PI and correlate well with each other. This also indicates to the relevance of the proposed model and the technique developed for studying it. The correlations between the components and the general PI are somewhat stronger in Riga than in Smolensk; the same is true for the interdependencies between the components (15 statistically significant correlations vs. 12, among them moderately strong correlations are 13 vs. 4 ).

The difference between the numbers of statistically significant correlations in two samples arose due to the following three components: "Philosophy of the profession", "Professional knowledge", "Professional Engagement Behaviors". Unlike the situation in Riga, where the respondents' answers in all components are closely linked with each other, Smolensk teachers' ideas about the philosophy of the profession do not correlate with professional knowledge and professional engagement behaviours. In addition, the "Professional knowledge" does not correlate with the "Professional engagement behaviours". On the whole, for Smolensk teachers the component "Philosophy of the profession" appears the most separated from all other components. Apart from the lack of correlations, it showed very weak interdependencies with the components "Professional roles" $(0,34)$ and "Cooperation with colleagues" $(0,33)$. This component, which in Smolensk sample has the highest mean rate (5.12) with the minimum dispersion (0.99) and the $\mathrm{CoV}(19.46 \%)$, proved to be, in essence, unsubstantiated. Thus, the respondents most consistently and highly appreciated the value of such assertions as "The teacher should promote a holistic physical, mental and social development of student's personality", "For the teacher, the professional value is the student's intellectual growth in the learning process", "Curriculum is a means for the development of student's personality", "In the pedagogical process, it is important to recognize individual student' achievements", "Effective teaching process is based on equitable cooperation of teacher and student," etc. However, in Smolensk these statements appeared the most separated from living practice and declarative. They did not show any relation with the professional knowledge of teacher or her/his perception of her/his professional mission in the social environment. The revealed negative trend requires further study.

By Spearman rank correlation coefficients, in the total sample of respondents statistically significant interdependencies between the questions in all the components of the contents of HEI teachers' PI have been identified. In all components, except component 4 , there appeared to be $4-6$ moderately strong correlations between questions. Though, 12 such correlations were found in component 4 ("Professional attitude to work"), which implies that the respondents' evaluations of the statements proposed in this block influenced each other stronger than in all other blocs. The core of "professional attitude to work" 
consists of two statements: "I think I have good cooperation with students" (5 moderately strong correlations plus 3 statistically significant weak correlations) and "I like to explain simply even complicated things" (5 moderately strong correlations). Thus, according to respondents, in the first place the professionalism of the teacher of HEI is manifested in teaching in cooperation with the students, as well as in the ability to make complicated things simple. It should be noted here that the Smolensk teachers attach more importance to the cooperation with students, subject-subject relationship with them (mean rates of this item in Smolensk and Riga are 5,04 and 4,97 respectively, CoV - 16,24 $\% / 19,33 \%$ ), while the respondents from Riga higher appreciate the lecturer's art (mean values are 5,13 in Riga and 4,93 in Smolensk, CoV 17,21 \% / 23,25 \%).

Only two statements of the component "Professional attitude to work" do not correlate with the others: "I understand that in my profession one often has to work overtime", and "My personal life is in balance with my work". Both samples of respondents showed high agreement with these statements (average scores in Riga and Smolensk are 4.76 and 5.15 respectively for the first statement, 4.35 and 4,39 for the second; $\mathrm{CoV}$ in all the cases are in the zone of reliability for the analysis). Nevertheless, the lack of correlations with other items of this block indicates that according to respondents, these statements are not essential features of professionalism. The coherence of private life and the profession is desirable, but it is not a key feature of professionalism, as well as readiness for working overtime is not a guarantee of professionalism or essential factor of professional skills.

\section{Conclusions}

- The obtained results show the relevance of the proposed model of the contents of HEI teachers' PI and the technique developed to study it. The elaborated technique can be applied as the tool of evaluation/self-evaluation of HEI teachers' PI to improve the educational process.

- All the proposed components of the model ("Philosophy of the profession", "Professional knowledge", "Professional roles", "Professional attitude to work", "Cooperation with colleagues", and "Professional engagement behaviours") have high average scores and correlate well with each other. All components have a statistically significant impact on the general PI.

- The lack of statistically significant differences in both survey samples points out that the PIs of teachers have much in common, regardless of the country of residence and features of the national educational systems. This fact is the additional significant indicator of the reliability of the model of teachers' PI. 
- Having relatively high mean values, the components "Cooperation with colleagues" and "Professional engagement behaviours" depend on individual and situational factors to a greater extent than other components (the general CoV for the component "Cooperation" is 30,93\% in Riga and more than $33 \%$ in Smolensk, $\mathrm{CoV}$ for "Professional engagement behaviours" is more than $33 \%$ in both countries).

- In both samples, the highest number of cross-correlations within one component has been found in the component "Professional attitude to work". The maximum number of correlations with other questions was found in two items: the statement about the subject-subject relationship with a student (more supported in Smolensk) and the methodical approach "to explain simply complicated things" (more strongly accented by respondents from Riga).

- Compared with Smolensk, the age structure of HEI teachers' stuff in Riga is less balanced, aged teachers prevail. In both countries the profession of university teacher is a predominantly female.

- For Smolensk teachers the component "Philosophy of the profession" is largely declarative and detached from teaching.

- Foreign languages and cooperation with foreign partners is the weak position in the PI of the Smolensk teachers; insufficient publication activity (especially that of young teachers) is the problem area in the PI of their colleagues in Riga.

\section{References}

Beijaard, D., Meijer, P. C., \& Verloop, N. (2004). Reconsidering research on teachers' professional identity. Teaching and Teacher Education, 2004, No 20, 107-128.

Bogdanova, T. (2016). Gender differences in professional activity of Smolensk high school lecturers and Riga teacher training and educational management academy. RPIVA 9. Starptautiskās zinātniskās konferences rakstu krājums TEORIJA PRAKSEI MŪSDIENU

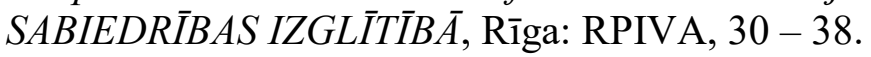

Bukor, E. (2011). Exploring Teacher identity: Teachers' Transformative Experiences of ReConstructing and Re-Connecting Personal and Professional Selves. Toronto: The University of Toronto.

Emerson, C. H. (2010). Counselor Professional Identity: Construction and Validation of the Counselor Professional Identity Measure. PhD thesis. Greensboro: The University of North Carolina.

Healey, A. C., \& Hays, D. G. (2011). Defining Counseling Professional Identity from a Gendered Perspective: Role Conflict and Development. Professional Issues in Counseling, On-Line Journal, Spring. Downloaded from http://www.shsu.edu/ piic/ DefiningCounselingProfessionalIdentityfromaGenderedPerspective.htm

Radulescu, C. (2013). Is Our Professional Identity Reflected in the European Documents on Education? Procedia - Social and Behavioral Studies, 78 (2013), 205 - 209. 
Silchenkova, S. Professional identity of a high school lecturer in Smolensk and Riga: differences by age and length of service (2016). RPIVA 9. Starptautiskās zinātniskās konferences rakstu krājums TEORIJA PRAKSEI MŪSDIENU SABIEDRİBAS IZGLITITIBA, Rīga: RPIVA, 230 - 236.

Špona, A. (2016). Augstskolu mācībspēku profesionālās identitātes pētīšana. RPIVA 9. Starptautiskās zinātniskās konferences rakstu krājums TEORIJA PRAKSEI MŪSDIENU SABIEDRĪBAS IZGLITTIBĀ, Rīga: RPIVA, 237-242.

Woo, H. R. Instrument construction and initial validation: professional identity scale in counseling. $\mathrm{PhD}$ thesis, University of Iowa, 2013

Сильченкова, Т. В., \& Ермолаева, Е. Б. (2016). Профессиональная идентичность педагога высшей школы Смоленска и Риги: различия по критерию наличия/отсутствия научной степени. Известия Смоленского государственного университета, №3 (35), Смоленск (Россия): Смоленский государственный университет, 355 - 362.

Шпона, А., Виднере, М., \& Ермолаева, Е. (2015). Сущность и структура профессиональной идентичности педагога. Известия Смоленского государственного университета, № 1 (29). Смоленск: Смол ГУ, 375 - 381. 